\title{
Can financial development influence economic growth: The sub-Saharan analysis?
}

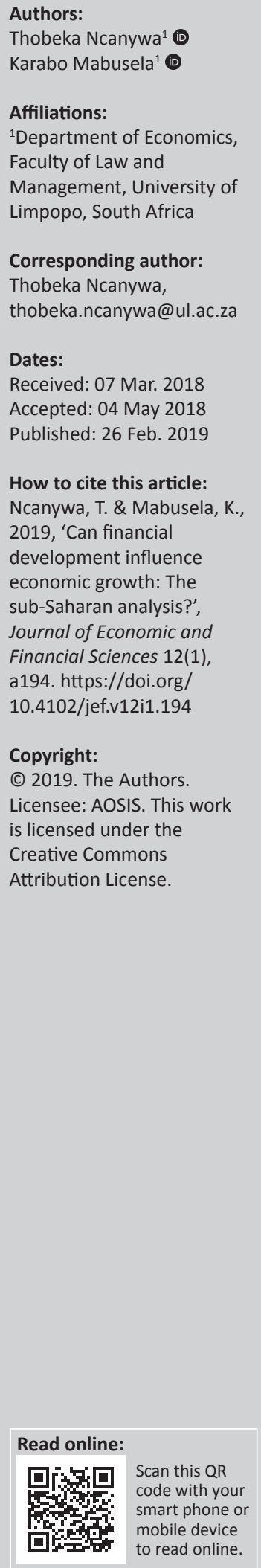

Orientation: Financial sector development in a vast majority of sub-Saharan African countries has the potential to reduce the volatility of growth.

Research purpose: This article is aimed at determining the influence of financial development on economic growth in selected sub-Saharan African countries.

Motivation for the study: In most of the sub-Saharan countries, financial sectors are among the world's least developed, and the absence of deep, efficient financial markets puts major constraints on economic growth.

Research approach/design and method: This article employed panel autoregressive and distributive lag model to determine the relationship between financial development and economic growth.

Main findings: The results indicated that there exists a short- and a long-run relationship between financial development and economic growth in the selected countries. In the long run, bank credit to the private sector and liquid liabilities have a positive influence on economic growth, with gross domestic savings exhibiting a negative influence.

Practical/managerial implications: This article makes recommendations that as financial stability, both globally and within countries, generates jobs and improves productivity, more effort should be made in ensuring an effective and sound developed financial sector system.

Contribution/value-add: The financial-economic growth nexus indicate that a well-functioning financial market development can promote economic growth. However, some controversies exist as some evidence indicated that a negative or positive financial development-growth nexus exists, so there was a need to find out what is the sub-Saharan case. Furthermore, there was a need to find development regulatory and macroeconomic policies that enhance growth.

\section{Introduction}

Over the past decades, there have been significant discussions on whether financial sector development can influence economic growth (Akinlo \& Egbetunde 2010). This dates back to when Joseph Schumpeter argued that the services provided by financial intermediaries are of importance in the development of any economy (Acaravci, Ozturk \& Acaravci 2009). As a result of this argument, both empirical and theoretical debates have resulted in a number of indicators of measuring financial sector development (Boulika \& Trabelisi 2002; Cecchetti \& Kharroubi 2012). Indicators included in the current study are bank credit to the private sector, ratio of liquid liabilities, ratio of bank deposits and gross domestic product (GDP) per capita. Central to the debate about the relationship between financial sector development and economic growth are the supply-leading and demand-leading responses. In terms of the latter, the real sector of the economy determines the level of financial sector development, and the supply-side financial sector development induces economic growth (Calderon \& Lin 2002; King \& Levine 1993; Ndlovu 2013).

There is a controversy about the relationship between financial sector development and economic growth. For instance, a well-functioning financial market development can promote economic growth (Ahmed \& Malik 2009; Beck et al. 2001; Loayza \& Ranciere 2006; Xu 2000). Financial development in the form of financial improvement organises financial surpluses from decisive savers and channels them into useful investment avenues (Acaravci et al. 2009; Bara, Mugano \& Le Roux 2016). This increases the rate of capital accumulation and, ultimately, the level of economic growth. In most African countries, financial innovation is generating increased economic activity by promoting financial inclusion, mobile money transfers and enabling remittances, which, in 
turn, have a positive impact on economic growth (Balago 2014; Bara, Mugano \& Le Roux 2017; Samargandi, Fidrmuc \& Ghosh 2014). With many African countries being characterised as developing, it is of importance to analyse the influence of financial development on the growth of the economy so as to enhance trade among them. In a vast majority of sub-Saharan countries, higher financial development has the potential to reduce the volatility of growth (Gulde et al. 2006; Hassan, Sanchez \& Yu 2011; Khan 2017). This is mainly because of the notion that financial development relaxes credit constraints, provides instruments to withstand adverse shocks and may influence savings and investment behaviour (Adu, Marbuah \& Mensah 2013).

In contrast, some evidence indicated a negative financial development-growth nexus (Ndlovu 2013; Rioja \& Valev 2004; Samargandi et al. 2014). Loayza and Ranciere (2006) found contradicting results as a negative relationship holds in the short run, and a positive one in the long run. Among the indicators used, Adu et al. (2013) established that money supply had a negative relationship. Furthermore, there was confirmation that a non-linear relationship exists in the short run, and others found the direction of causality coming from growth to financial development (Arcand \& Panizza 2012; Law \& Singh 2014; Obradovic \& Grbic 2015; Quartey \& Prah 2008; Samargandi et al. 2014).

Because of these controversial debates, it was interesting to investigate if indicators of financial sector development can influence economic growth. There was a need to find development regulatory and macroeconomic policies that enhance growth. This study attempts to determine this aim using a panel data analysis of five selected sub-Saharan African countries (Botswana, Ghana, Kenya, Nigeria and South Africa). The choice of these developing countries is based on the fact that their economies have an average level of financial development because of their socio-economic, political and institutional history (Akinlo \& Egbetunde 2010). Until the implementation of reforms in most subSaharan African countries in the mid-1980s, commercial banks dominated the banking system. Given the low level of development of stock and bond markets in sub-Saharan Africa, banks play a crucial intermediary role and represent the main source of external capital for companies (World Bank 2016). On the contrary, progress is made in financial development even though there remains considerable scope for further developments. This was partly as a result of improvements in the institutional framework of finance such as the establishment of commercial courts and alternative dispute resolution systems, credit reference bureaus and macroeconomic stability (Beck et al. 2001). The structure of this paper is as follows: the next section presents stylised facts, followed by the 'Literature review' section. The 'Methods' section examines the research methodology of the study; the 'Empirical results and discussion' section discusses the results and the 'Conclusion and recommendations' section concludes and provides recommendations of the study.

\section{Stylised facts}

In this section, key features of the financial system and economic growth in the selected sub-Saharan countries are highlighted. Financial sectors in most sub-Saharan African countries operate within weak institutional environments and are among the least developed in the world (European Investment Bank [EIB] 2016). Karikari, Mensah and Harvey (2016) attest that this underdevelopment can affect poverty reduction and economic growth. This is because limited and inadequate access to credit contributes significantly to low productivity in agriculture in rural areas. It limits the contributions of small and medium-sized enterprises to the private sector development. Furthermore, it can slow the deepening of the banking sector in oil-exporting countries as declining export revenues affect their foreign assets. The financial indicators adopted in the study are bank credit to the private sector as a percentage of GDP, liquid liabilities as a percentage of GDP and gross domestic savings as a percentage of GDP. It is believed that economic growth in sub-Saharan countries is relatively low, averaging between $-10 \%$ and $10 \%$ (Khan 2017).

\section{Botswana}

Before independence, the development of Botswana's financial sector was slow, with only two commercial banks in operation, both of which were incorporated outside the country. By the end of 2008, the number has grown to seven commercial banks in the country (Moffat 2009). In the 1980s and the early 1990s, Botswana's financial sector was not diversified; it lacked competition and was characterised by a limited range of financial institutions (Siane 2005). During this period, commercial banks did not have the upper hand as lenders, but government through its lending to parastatals was the larger lender. However, changes happened after the introduction of financial sector reform, with commercial banks dominating the financial sector (Siane 2005).

The financial sector in Botswana is divided into two segments: the banking sector, which is regulated and supervised by the Bank of Botswana, and the non-banking sector, which is regulated by the Non-Bank Financial Institutions Regulatory Authority. The financial sector is dominated by foreigncontrolled banks, particularly South Africa's First National Bank and Standard Bank, and UK banks Barclays and Standard Chartered, which make up four of the five biggest banks in Botswana (EIB 2016). The country has also adopted the financial sector supervisory regulations and practices that have evolved in line with international norms, which fully comply with Basel II and III principles (Bank of Botswana 2015). Over the past two decades, Botswana's financial sector has experienced rapid growth. This is because of a favourable economic climate and well-targeted supervision of the Bank of Botswana, among other reasons. The sector now has better technology, a wide range of products and more bank branches. This is indeed important not only at national but also at individual levels (Madigele \& Mogomotsi 2016). However, more than 50 years after 
independence and the achievement of remarkable economic development, Botswana is still struggling to have universal financial inclusion for its people (Madigele \& Mogomotsi 2016). Despite increase in the number of financial institutions since independence, Botswana's financial sector is still relatively shallow (Akinboade 1998).

In 1988, Botswana had a substantial increase in the annual growth rate as its government revenue as a percentage of GDP reached a peak of $64 \%$, and gross domestic savings were relatively high at 50\% (Maipose 2008). Gross domestic savings declined significantly during the 2008 financial crisis. Of all the countries, Botswana has a high ratio of gross domestic savings to GDP. This is a result of prudent fiscal spending by the government rather than because of high household savings (Amusa \& Busani 2013). According to a report by the Bank of Botswana (2009), the growth in savingsGDP ratio can be attributed to the effectiveness of monetary policy, which has ensured that there is a constant and significant capital inflow from private sources. The high liquid liabilities to GDP ratio correspond to the global financial crisis in 2008-2009. During the crisis, a majority of people were sceptical about holding their money in assets and, as a result, the rate at which assets could be exchanged for idle money increased significantly (Rashti, Araghi \& Shayeste 2014). This was done so that the impact could be minimal as much as possible.

\section{Ghana}

Ghana has undergone a process of financial sector restructuring and transformation as an integral part of a comprehensive financial sector liberalisation programme (Quartey 2005). The financial system is now dominated by banks, with bank loans being the primary source of external financing for domestic companies. This came after the Government of Ghana, in association with the World Bank, introduced financial sector reforms with the Financial Sector Adjustment Programme (FINSAP) in 1987 (Antwi-Asare \& Addison 2000). From the programme, seven distressed banks were restructured, and their non-performing assets were cleaned up to restore profitability and viability in the banking system (Adu et al. 2013). Even though there still remain a number of cross-cutting challenges, including access to credit by the private sector, and the high cost of credit which tends to militate against small-scale businesses, authorities continue to work on these challenges (Ackah \& Asiamah 2014). It is further argued that the medium-term national development policy framework (Ghana Shared Growth and Development Agenda 2010-2013) is the overarching policy framework that provides broad policy parameters for economic growth in Ghana. The policy thrust of Ghana's second medium-term Private Sector Development Strategy (PSDS II) is about developing a thriving private sector that creates jobs and enhances livelihoods for all.

Ghana experienced a sharp increase in economic growth in 2011 as a result of the launch of crude oil production and strong performance of the gold and cocoa sector. It is evident that Ghana always had a relatively low ratio of liquid liabilities to GDP, with the highest at just about $29 \%$ of GDP (EIB 2016). This implies that the majority of its currency interest-bearing liabilities are held within the banking system. Ghana is the only country with the lowest ratio of liquid liabilities to GDP, which did not exceed $40 \%$ from 1980 to 2014, although in 2001-2005, a moderate increase and annual growth rate increased by small margins. For Ghana, the ratio of bank credit to the private sector is significantly low, with the highest value recorded at just about $20 \%$ in 2005 . Even so, the ratio of bank credit to the private sector as a proportion of GDP for Ghana is rising from 1980 to present at a slow rate. The trend of the percentage of liquid liabilities to GDP is significant, with the lowest at just $10 \%$ for Ghana.

\section{Kenya}

Kenya's financial system comprises numerous commercial banks, non-bank financial institutions, a range of insurance companies and a stock exchange (United Nations 1997). In the late 1980s and the early 1990s, weaknesses in Kenya's financial system became more apparent. The Central Bank of Kenya experienced loss in control of money supply, accelerated rates of money supply growth and high inflation (United Nations 1997). This also resulted in distress in Kenya's banking system and lack of effectiveness to carry out monetary policy. Recently, Kenya's financial sector has relatively well developed and diversified. However, major structural impediments prevent it from reaching its full potential (Deloitte 2016).

The annual growth rate for Kenya is hovering around $0 \%-7 \%$, with a sharp decline of $0 \%$ in 2007-2008 (Macias \& Massa 2009). The country enjoys a higher level of credit channelled to the private sector and higher deposits in financial institutions than other sub-Saharan African and low-income countries (Beck \& Fuchs 2004). The percentage of liquid liabilities to GDP ratio has been moderate for 1980-2003, but from 2004 onwards, it has been rising, with the highest value in 2012. In 2011-2012, Kenya experienced a decline in its annual growth rate as a result of the economic crisis and political instability. This was also evidenced by the Euro crisis in the second half of 2011, the rapid rise of oil prices in the first half of 2011 and the drought experienced by the country (World Bank 2016).

\section{Nigeria}

Nigeria has witnessed development in its financial sector, which affected key sectors of the economy. The Nigerian financial system can be divided into two sub-sectors: formal and informal sectors. The informal sector has neither formalised institutional framework nor formal structure of rates, and comprises local money lenders, thrift collectors, savings and loan associations (Nzotta \& Okereke 2009; Olofin \& Afangideh 2008). This sector is poorly developed and not incorporated into the formal financial system and, as such, its exact size and influence on the economy remain unknown, 
and a matter of speculation. The formal sector, on the other hand, comprises bank and non-bank financial institutions. It comprises the money market, the capital market and institutions and channels that facilitate the smooth intermediation of financial transactions in the economy (Balago 2014).

There was a sharp decline in the annual growth rate in 1981 when the National Development Plan 1981-1985 was introduced. This coincided with the inception of the global economic recession, which sparked declining foreign exchange earnings, balance of payment disequilibrium and unemployment (Chete et al. 2014). In 2004, the country experienced a sharp increase in its economic growth. Ajide (2014) believes that this was as a result of remarkable improvement in the inflows of foreign direct investment (FDI), which ultimately led to the increased supply of indicators of financial sector development. The ratio of bank credit to the private sector increased substantially between 2006 and 2009, with a sharp decline in 2010. Oluitan (2012) indicates that the Nigerian economy largely depends on the export of oil, which explains the relatively low ratio of bank credit to the private sector as proportion of GDP (EIB 2016). In 2009, Nigeria also experienced a high ratio of liquid liabilities to GDP. Gross domestic savings to GDP ratio trend has been fluctuating since the 1980s, but in 1999, there was a drastic increase, which corresponds to an increase in economic growth for the same year. In 1999, there was considerable improvement in some of the components of economic freedom, like the size of government, access to sound money, freedom to trade internationally and the regulation of credit, labour and business (Ajide 2014).

\section{South Africa}

South Africa's financial sector is well developed and highly sophisticated with a wide range of financial institutions and instruments (National Treasury RSA 2011; Odhiambo 2010). Although the financial depth has improved considerably in South Africa, it was not always the case. During 1985-1989, there was a decline in economic growth, which was mainly attributed to trade and financial sanctions imposed on the country, political unrest, and the debt crisis, which inhibited prospects for substantial capital inflows (Odhiambo 2010). Until the 1950s when banking services began to diversify, the private banking sector was dominated by commercial banks. During the same period, these banks had avoided services such as personal loans, property leasing and credit card facilities. But since then, new institutions such as discount houses, merchant banks and general banks emerged to meet this demand (Akinboade \& Makina 2006).

Post-1994, the contribution of the financial sector was approximately $20 \%$ to economic activities measured in terms of GDP, of which the banking sector contributed around 35\% of this value added (Djoumessi, 2009). In the 1980s, the annual growth rate declined significantly because of political transition and fall in public saving (Harjes \&
Ricci 2008). The country further experienced a sharp decline in the growth rate in 1992, after the recession experienced in 1991 and 1992 (Lehlola 2017). The bank credit ratio to the private sector as a percentage of GDP was significantly high, exceeding 80\% of GDP from 1991 to 2015. Liquid liabilities to GDP ratio has the highest value of about $55 \%$ of GDP for 1998 compared to $55 \%$ in Botswana in 2009. The country has been experiencing decreasing gross domestic savings from 1989 , with significant increase in 2008 , only for it to decrease in 2009 .

\section{Literature review}

This section discusses theories and empirical evidence related to the relationship between economic growth and financial development. The theory of endogenous growth was developed by Romer (1986) as a reaction to omissions and deficiencies in the Solow-Swan neoclassical growth model. The endogenous theory is a modern theory which explains the long-run growth rate of an economy on the basis of endogenous, as against exogenous, factors of the neoclassical growth theory (Levine 1997). The emergence of this theory has created a wide range of interest in the influence of financial sector development in stimulating economic growth (Samargandi et al. 2014). The theory highlights the role played by the financial sector in positively influencing economic growth through the promotion of investment and growth, whereby financial intermediaries enable a high return on capital (Samargandi et al 2014). According to this theory, financial intermediaries and securities market allow investors and emerging business owners to embark on innovative activities that can promote economic growth. In essence, innovative activities will, in the end, influence the behaviour of indicators of financial sector development either through credit provided to them by banks or through the number of bank deposits that arise from those innovative activities. As a result, the level of financial development can forecast future economic growth well. It can also be the effect of financial intermediaries on economic growth through increasing investment efficiency (Rashti et al. 2014).

The financial development theory advocates that financial instruments, markets and institutions arise to mitigate the effects of information and transaction costs (Levine 1997). The primary function of the financial system is to enable the allocation of resources through space and time in an uncertain environment. Financial sector development is defined as the process of strengthening and diversifying the provision of financial services to meet the requirements of economic growth in an effective and efficient manner, thereby supporting and stimulating economic growth (Mogale 2014). According to Levine (2005), financial systems may influence savings rate, investment decisions, technological innovation and, ultimately, long-run economic growth.

Early economic growth theorists argue that economic development is a process of innovations, whereby the 
interactions of innovations in both the financial and real sectors provide a driving force for vigorous economic growth (Hassan et al. 2011). The new growth theory argues that financial intermediaries and markets appear endogenously in reaction to market completeness, thereby adding to longterm growth. At a broader level, a strong and efficient financial system stimulates growth by channelling resources to their most productive uses, fostering a more efficient allocation of resources (Estrada, Park \& Ramayadi 2010). Another school of thought, the McKinnon-Shaw school's main policy implication is that government constraints on the financial sector deter financial development and, ultimately, reduce growth. Therefore, government restrictions have an influence on how the banking system behaves and influences economic growth (Al-Zubi, Al-Rjoub \& Abu-Mhareb 2006).

By using the autoregressive distributive lag model in the pooled mean group setting, the results from Samargandi et al. (2014) indicated that there is an inverted U-shaped relationship between finance and growth in the long run. However, in the short run, the relationship was insignificant, indicating that too much finance could exert a negative influence on growth in middle-income countries. Odhiambo (2009) examined the dynamic relationship between interest rate reforms, financial development and economic growth, and the results exhibited a demandfollowing path. The study indicated that increased economic growth leads to more demand for services provided by financial institutions. These results were consistent with those of Obradovic and Grbic (2015), whose analysis indicated that the process of economic growth contributes to the process of financial development. Other results of the study exhibited a supply-following hypothesis, in which the development of a robust financial sector can spur economic growth (Adu et al. 2013).

Levine (1997) found that countries with larger banks and more dynamic stock markets had economies that grew faster over successive decades. The study determined whether financial sector development influenced economic growth through total factor productivity (TFP) growth and domestic capital in 35 developing countries. The results showed that financial sector development affects per capita GDP mainly through its role in efficient resource allocation, and not on its effects on capital accumulation (Ahmed \& Malik 2009). The findings predicted that a better-functioning financial sector accumulates domestic capital, which, in turn, spurs economic growth. The results from the study of Samargandi et al. (2014) indicate that financial development is negatively associated with economic growth in the long run when one considers all middle-income countries in the study. The results were consistent with that of Loayza and Ranciere (2006), who also found that financial development negatively influences economic growth in the short run.

The financial development-economic growth nexus has received attention in economic research, with the first positive correlation between growth and indicators of financial development documented by Goldsmith (1989), who argued that a more developed financial market promotes economic growth by mobilising savings to finance the most productive investments. The results from Beck et al.'s (2001) study were consistent with those of Ahmed and Malik (2009), who examined data for 63 countries, and in their findings, argued that financial intermediaries had a large and positive effect on TFP growth that enabled the growth of GDP. Calderon and Lin's (2002) study found that in 109 developing and industrial countries, financial development generally leads to economic growth in which financial deepening in many countries has yielded the desired results of a more prosperous economy. The Granger causality from financial development to economic growth and from economic growth to financial development coexisted in 87 of the developing countries and 22 of the industrial countries. This implied that financial deepening stipulated and simultaneously propelled economic growth.

According to Hassan, Sanchez and Yu (2009), it is typical in a vector autoregressive analysis that a variable explains a huge proportion of its forecast error variance. The impulse response function and variance decomposition were employed for forecasting in the Organisation of Islamic Corporations during 1980-2005. The results from the analysis indicated that shocks in growth cause a weakening in all financial measures, but the effects positively changed in the long term. Another factor that could influence the financial sector in the future was innovations in the financial development as they could cause a decline in growth, thereby becoming consistent with the supply-leading hypothesis. The impulse response function results indicated that trade openness and government spending influenced domestic credit to the private sector, and at the same time, any change in inflation could really hurt financial development (Hassan et al. 2009).

From the literature review, it is evident that some contradicting views exist in the financial developmenteconomic growth nexus. Moreover, the relationship between financial development and economic growth is complex as it could be affected by, among other reasons, government intervention in the form of reforms. This is largely because of the fact that various sectors of the economy depend on the financial sector for growth, and therefore, without the input of the financial sector, economic growth seems unrealistic as no economy performs without finance (Ekmekcioglu 2012). Therefore, there is a need to conduct a study that would clarify this challenge.

\section{Methodology Data collection}

The model of the study consists of four variables with secondary yearly time series data. Variables to be used are bank credit to the private sector (BCG), liquid liabilities (LLG), bank deposits (BDG) and economic growth (GDP). 
The data for these variables were sourced from the World Bank Databank for the period 1980-2014. The selected sub-Saharan African countries that were analysed in this study were Botswana, Ghana, Kenya, Nigeria and South Africa. The countries were selected on the basis of data availability for the period to be analysed and the average level of financial development. The estimated model comprises of large time series and small cross-sectional panel case (large T, small N).

\section{Model specification}

To achieve the aim of the influence of financial sector development on economic growth, the study referred to some works by Cecchetti and Kharroubi (2012), Beck et al. (2001), Obradovic and Grbic (2015) and others discussed in the literature review section. In addition, the endogenous growth and financial development theories were adopted to accomplish the set objectives. The following linear relationship is used and is illustrated as follows:

$$
G D P_{i t}=\alpha_{0}+\alpha_{1} B C G_{i t}+\alpha_{2} L L G_{i t}+\alpha_{3} B D G_{i t}+\varepsilon_{i t} \quad \text { [Eqn 1] }
$$

Where GDP is the annual growth rate of gross domestic product that is used as a proxy for economic growth for selected sub-Saharan African countries, BCG represents bank credit to the private sector as proportion of GDP, LLG is the ratio of liquid liabilities to GDP and BDG is the ratio of bank deposits as a percentage of GDP.

\section{Estimation techniques}

\section{Panel data unit root tests}

The study employed the panel data unit root testing as the data used were selected from different countries. The order of integration was determined to guard against issues of obtaining spurious regressions, model misspecifications and inconsistent and unrealistic results. According to Krentz (2012), in panel data, the analysis of non-stationarity requires the establishment of new unit root tests coping with both time series and cross-section dimension of the data. Recent literature suggests that panel-based unit root tests have a higher power than unit root tests which are based on individual time series (Krentz 2012; Ngongang 2015; Ramirez 2006). The power of a test is defined as the probability of rejecting the null hypothesis that each time series contains a unit root. Like time series unit root, most panel unit root tests are designed to test the null hypothesis of a unit root in each individual panel series (Pesaran, 2012). The study computed the Im, Pesaran and Shin (IPS 2003) and the Fisher-type tests using augmented Dickey-Fuller and Phillips-Perron (ADF \& PP) unit roots. The Im, Pesaran and Shin (IPS) and Fisher ADF \& PP tests were chosen because they allow heterogeneous coefficients and persistent parameters to move freely across sections (Bidirici \& Bohur 2015; Hoang 2007; Khan \& Abbas 2016).

\section{Panel data cointegration tests}

When testing for cointegration, several additional issues are of potential importance. These include heterogeneity in the parameters of the cointegrating relationships, heterogeneity in the number of cointegrating relationships across countries and the possibility of cointegration between the series from different countries (Verbeek 2004). The most popular tests in panel cointegration are the Pedroni test, Kao test and the Fisher (combined Johansen) test. Given the results of the panel unit root test, the study employs the Pedroni (EngleGranger based), Kao (Engle-Granger based) and Fisher (combined Johansen) tests.

Pedroni (1997) employs four panel statistics and three group panel statistics to test the null hypothesis of no cointegration against the alternative hypothesis of cointegration. Ramirez (2006) opines that the first-order autoregressive term in the panel statistics is assumed to be the same across all the cross sections, and in the group panel statistics, the parameter is allowed to vary over cross sections. The first category of the four statistics is defined within-dimension-based statistics and includes a variance ratio statistic, a non-parametric Phillips and Perron-type $p$-statistic, a non-parametric Phillips and Perron type $t$-statistics and a DF type $t$-statistic. The second category of the three-panel cointegration statistics is defined as between-dimension-based statistics and is based on a group mean approach (Bildirici 2004).

The Kao test follows the same basic approach as the Pedroni test but specifies cross-section-specific intercepts and homogenous coefficients on the first-stage regressors. Furthermore, Fisher (combined Johansen) test was proposed by Maddala and $\mathrm{Wu}$ (1999) as an alternative approach to testing the cointegration in panel data by combining tests from individual cross sections to obtain a test statistic for the full panel.

\section{Autoregressive distributed lag}

Autoregressive distributed lag (ARDL) models are standard least squares regressions which include lags of both dependent and independent variables as regressors. In panel settings with individual effects, standard regression estimation of ARDL models is problematic because of the bias caused by correlation between the mean-differenced regressors and the error term. This bias only vanishes for large numbers of observations and cannot be corrected by increasing the number of cross sections. To address this problem, a number of small-large, dynamic panel data general methods of moments (GMM) estimators have been developed, for example, ArellanoBond (Verbeek 2004).

In large data sets, these assumptions underlying dynamic GMM are often inappropriate, and the estimator breaks down. In this case, a popular alternative is the pooled mean group (PMG) estimator of Pesaran, Shin and Smith (Pesaran 2012). This model takes the cointegration form of the simple 
ARDL model and adapts it for a panel setting by allowing the intercepts, short-run coefficients and cointegrating terms to differ across cross sections. The PMG is written as:

$$
\Delta Y_{i t}=\Phi E C_{i t}+\sum_{j=0}^{q-1} \Delta \mathrm{X}_{i t-j}{ }^{\prime} \beta_{i j}+\sum_{j=1}^{p-1} \lambda_{i j} * \Delta y_{i t}+\varepsilon_{i t}
$$

Where

$$
E C_{i t}=y_{i t-1}-x_{i t}^{\prime} \theta
$$

It is then assumed that both the dependent variable and the regressors have the same number of lags in each cross section. It is further assumed that the regressors (Xs) have the same number of lags $q$ in each cross section, but this assumption is not strictly required for estimation. To show the long-run and short-run relationships between financial development and economic growth, the study employs the ARDL. The test is a simple technique because it allows the cointegration relationship to be estimated by ordinary least squares once the lag order of the model is identified (Egbetunde \& Fasanya 2013).

\section{The impulse response function and variance decomposition}

Impulse response functions show the effects of shocks on the adjustment path of the variables. Forecast error variance decompositions measure the contribution of each type of shock to the forecast error variance. Both computations are useful in assessing how shocks to economic variables reverberate through a system (Den Haan 2011). The study employed the two tests in order to forecast how indicators of financial sector development will influence economic years in the years to come. They also analysed any shocks that may influence the model and thereby cause changes in the control variable (Asteriou \& Hall 2011).

\section{Empirical results and discussion Unit root tests results}

The results from the Im, Pearson and Shin test, FisherADF test and Fisher-PP test are presented in Table 1. These unit root results are for the variables economic growth (GDP), bank credit to the private sector (BCG), liquid liabilities (LLG) and gross domestic savings (BDG). Financial sector development indicators appear to be stationary after being differenced once. Economic growth appears to be stationary at level form at all the test equations reported in Table 1 . The notion of stationarity is that the probability value should be less than 0.05 , and the $t$-statistic should be less than all the levels of critical values. The results indicated that the panel model is

\begin{tabular}{|c|c|c|c|c|}
\hline Variable & Test & Test equation & Level & 1st difference \\
\hline \multirow[t]{8}{*}{ GDP } & Im, Pearson and Shin & Individual intercept & 0.0000 & - \\
\hline & & Individual intercept and trend & 0.0000 & - \\
\hline & Fisher-ADF & Individual intercept & 0.0000 & - \\
\hline & & Individual intercept and trend & 0.0000 & - \\
\hline & & None & 0.0000 & - \\
\hline & Fisher-PP & Individual intercept & 0.0000 & - \\
\hline & & Individual intercept and trend & 0.0000 & - \\
\hline & & None & 0.0000 & - \\
\hline \multirow[t]{7}{*}{ BCG } & Im, Pearson and Shin & Individual intercept & 0.9834 & 0.0000 \\
\hline & & Individual intercept and trend & 0.0669 & 0.0000 \\
\hline & Fisher-ADF & Individual intercept & 0.6421 & 0.0000 \\
\hline & & Individual intercept and trend & 0.1167 & 0.0000 \\
\hline & & None & 0.9793 & 0.0000 \\
\hline & Fisher-PP & Individual intercept & 0.9058 & 0.0000 \\
\hline & & None & 0.9977 & 0.0000 \\
\hline \multirow[t]{8}{*}{ LLG } & Im, Pearson and Shin & Individual intercept & 0.3981 & 0.0000 \\
\hline & & Individual intercept and trend & 0.0162 & 0.0000 \\
\hline & Fisher-ADF & Individual intercept & 0.4410 & 0.0000 \\
\hline & & Individual intercept and trend & 0.0262 & 0.0000 \\
\hline & & None & 0.8053 & 0.0000 \\
\hline & Fisher-PP & Individual intercept & 0.7093 & 0.0000 \\
\hline & & Individual intercept and trend & 0.0968 & 0.0000 \\
\hline & & None & 0.9074 & 0.0000 \\
\hline \multirow[t]{6}{*}{ BDG } & Im, Pearson and Shin & Individual intercept & 0.2582 & 0.0000 \\
\hline & & Individual intercept and trend & 0.1028 & 0.0000 \\
\hline & Fisher-ADF & Individual intercept & 0.2725 & 0.0000 \\
\hline & & Individual intercept and trend & 0.1159 & 0.0000 \\
\hline & & None & 0.6979 & 0.0000 \\
\hline & & None & 0.8909 & 0.0000 \\
\hline
\end{tabular}

TABLE 1: Panel unit root results, 1980-2014.

GDP, annual growth rate of gross domestic product; BCG, bank credit to the private sector as proportion of GDP; LLG, ratio of liquid liabilities to GDP; BDG, ratio bank deposits as a percentage of GDP; ADF, Augmented Dickey-Fuller; PP, Phillips-Perron. 
TABLE 2: VAR Lag order selection criteria, 1980-2014.

\begin{tabular}{|c|c|c|c|c|c|c|}
\hline Lag & LogL & LR & FPE & AIC & SC & $\mathrm{HQ}$ \\
\hline 0 & -2029.711 & NA & $1.23 e+09$ & 32.28113 & 32.37117 & 32.31771 \\
\hline 1 & -1477.447 & 1060.698 & $247126.1^{*}$ & $23.76900 *$ & $24.21920 *$ & 23.95190* \\
\hline 2 & -1469.368 & 15.00367 & 280462.0 & 23.89473 & 24.70509 & 24.22395 \\
\hline 3 & -1457.103 & 21.99810 & 298182.6 & 23.95402 & 25.12455 & 24.42957 \\
\hline 4 & -1446.922 & 17.61478 & 328240.0 & 24.04639 & 25.57708 & 24.66826 \\
\hline 5 & -1429.646 & 28.79334 & 323573.0 & 24.02613 & 25.91699 & 24.79433 \\
\hline 6 & -1401.181 & $45.63542 *$ & 267825.9 & 23.82827 & 26.07928 & 24.74278 \\
\hline 7 & -1394.970 & 9.562128 & 316707.2 & 23.98365 & 26.59483 & 25.04450 \\
\hline 8 & -1381.041 & 20.56160 & 332702.1 & 24.01653 & 26.98787 & 25.22369 \\
\hline
\end{tabular}

VAR, Vector autoregressive; LR, sequential modified LR test statistic (each test at 5\% level); FPE, Final prediction error; AIC, Akaike information; criterion; SC, Schwarz information criterion; HQ, Hannan-Quinn information criterion; *, indicates a chosen criteria.

TABLE 3a: Panel Johansen cointegration Trace test results, 1980-2014.

\begin{tabular}{|c|c|c|c|c|c|}
\hline Test & Hypothesised number of CE(s) & Eigenvalue & Trace statistic & 0.05 Critical value & 0.01 Critical value \\
\hline \multirow[t]{4}{*}{ Trace } & None** & 0.282958 & 69.28117 & 47.21 & 54.46 \\
\hline & At most 1 & 0.052930 & 15.39653 & 29.68 & 35.65 \\
\hline & At most 2 & 0.034277 & 6.586644 & 15.41 & 20.04 \\
\hline & At most 3 & 0.936409 & 0.936409 & 3.76 & 6.65 \\
\hline
\end{tabular}

**, denotes rejection of the hypothesis at the $5 \%$ and $1 \%$ levels; CE (s), cointegrating equation(s)

Trace test indicates 1 cointegrating equation(s) at both $5 \%$ and $1 \%$ levels.

TABLE 3b: Panel Johansen cointegration maximum eigenvalue test results, 1980-2014.

\begin{tabular}{|c|c|c|c|c|c|}
\hline Test & Hypothesised no. of CE(s) & Eigenvalue & Maximum-Eigen statistic & 0.05 Critical value & 0.01 Critical value \\
\hline \multirow{4}{*}{$\begin{array}{l}\text { Maximum } \\
\text { eigenvalue }\end{array}$} & None** & 0.282958 & 53.88464 & 27.07 & 32.24 \\
\hline & At most 1 & 0.052930 & 8.809556 & 20.97 & 25.52 \\
\hline & At most 2 & 0.034277 & 5.650235 & 14.07 & 18.63 \\
\hline & At most 3 & 0.005764 & 0.936409 & 3.76 & 6.65 \\
\hline
\end{tabular}

**, denotes rejection of the hypothesis at the $5 \%$ and $1 \%$ levels; CE (s), cointegrating equation(s)

Max-eigenvalue test indicates 1 cointegrating equation(s) at both $5 \%$ and $1 \%$ levels.

TABLE 3c: Pedroni panel cointegration test results (GDP BCG LLG BDG).

\begin{tabular}{lc}
\hline Statistics & Probability \\
\hline Panel & \\
Panel v-stat & 0.9915 \\
Panel rho-stat & 0.0081 \\
Panel PP-stat & 0.0000 \\
Panel ADF-stat & 0.0000 \\
Group & \\
Group rho-stat & 0.2268 \\
Group PP-stat & 0.0000 \\
Group ADF-stat & 0.0000 \\
\hline
\end{tabular}

GDP, annual growth rate of gross domestic product; $B C G$, bank credit to the private sector as proportion of GDP; LLG, ratio of liquid liabilities to GDP; BDG, ratio bank deposits as a percentage of GDP; Null hypothesis: No cointegration; PP, Phillips Perron; ADF, Augmented Dickey Fuller.

Note: Number of countries $(N)=5$ and periods $(T)=34$; Automatic lag length selection based on SIC with a max lag of 1 .

integrated of different orders: I (1) and I (0). This gives way to use cointegration tests and the autoregressive distributive lag models to find estimates and a long-run relationship in the panel.

\section{Panel data cointegration test results}

Before computing panel cointegration tests, the lag selection criteria were employed to determine the number of lags used in the analysis. The lag length describes the method for selecting lags $k$ for each individual test specification. In the lag selection criteria, we looked at the Akaike criterion (AIC), Schwarz criterion (SC), Hannan-Quinn criterion (HQ), modified Schwarz and modified Hannan-Quinn. These criteria specify the maximum lag(s) to be used.
Table 2 indicates that lag length 1 has been chosen by most criteria.

The panel of Johansen, Pedroni, Kao and Johansen Fisher cointegration tests was employed to examine the long-run relationship between economic growth and financial development indicators (Table 3a-e). The panel Johansen cointegration test presented a panel version of the individual Johansen cointegration tests. This encompasses the trace test and the maximum eigenvalue test, which indicate if there exists a long-run relationship between the variables in the model. From Table $3 a-b$, the null hypothesis is rejected at none in both the trace and maximum eigenvalue tests. If the trace and maximum eigen statistics are greater than the critical value at both $1 \%$ and $5 \%$, then there is a presence of a cointegrating equation (Table $3 a-b)$. Both tests indicate one cointegrating equation, implying the presence of a long-run relationship between the variables in the study. The cointegrating equation also gives the go-ahead in estimating the influence of financial sector development on economic growth in the five sub-Saharan African countries.

Pedroni panel cointegration consists of the seven statistics, each of which has its own probability. The probability of each statistic will either reject or fail to reject the null hypothesis depending on the $p$-value. Once $p$-values are determined, we can assess how many cointegration relationships exist in the model. The results of the Pedroni panel cointegration tests 
indicate that 8 of the 11 statistics do not reject the null hypothesis of no cointegration at the conventional size of 0.05 (Table 3c). The tests indicate three cointegrating equations as three statistics reject the null hypothesis of no cointegration. Therefore, there is a long-run relationship in the economic growth-financial development model.

The Kao cointegration follows the same logic as the Pedroni cointegration, where the decision of cointegration is determined by the $p$-value whether to reject the null hypothesis (Kao 1999). The results of the Kao panel cointegration test are presented in Table $3 \mathrm{~d}$ with the deterministic trend specification of individual intercept. The null hypothesis is that of no cointegration and the notion is that if the $p$-value is less than 0.05 , the null hypothesis is not rejected. The Kao test results indicate no presence of cointegrating the specified model, and therefore, no long relationship exists. This is in agreement with the results obtained by Law and Singh (2014) and Quartey and Prah (2008), who did not find a relationship between economic growth and financial development.

The Johansen Fisher panel combines the trace test and the maximum eigenvalue test to provide two separate Fisher stats. Like the other two panel cointegration tests, the probability value determines the existence or no existence of cointegration. Table 3e provides the Johansen Fisher panel cointegration test results, which indicate one cointegrating equation from both trace and maximum eigenvalue. For the

TABLE 3d: Kao panel cointegration test results.

\begin{tabular}{lcc}
\hline Variable & $\boldsymbol{t}$-statistic & Probability \\
\hline ADF & -1.662285 & 0.0482 \\
Residual variance & 26.05697 & - \\
HAC variance & 5.609073 & - \\
\hline
\end{tabular}

ADF, Augmented Dickey Fuller; HAC, heteroscedasticity and autocorrelation consistent.
Johansen Fisher panel cointegration tests, if the $p$-value is less than 0.05 , this indicates cointegration. From Table 3e, at none the $p$-values from both the trace test and maximum eigenvalue are less than 0.05 , which means that at none, there is one cointegrating equation. Looking at most 1 in Table $3 \mathrm{e}$, the $p$-values are greater than 0.05 , meaning that there is no cointegrating equation. Therefore, the conclusion is that there is one cointegrating equation in the specified model. This means that there exists a long-run relationship between the variables in the model. These results are consistent with those of the panel Johansen cointegration test as both indicate 1 cointegrating equation from the trace and maximum eigenvalue test. The fact that there is a long-run relationship is in line with the works by Loayza and Ranciere (2006), Adu et al. (2013), Cecchetti and Kharroubi (2012) and Law, AzmanSaini and Ibrahim (2013).

Like the panel cointegration tests, the individual crosssection results indicate that in each country there exists a long-run relationship between economic growth, bank credit to the private sector, liquid liabilities and domestic savings.

Table 4 presents the cross-section results of the five countries in the study. The first hypothesis is that of none, and the second one is that of at most 1 . The notion is that if $p$-value is less than 0.05, this indicates cointegration. At none, for Botswana, the maximum eigenvalue indicates cointegration with the trace, indicating no cointegration. This means that for Botswana the results indicate one cointegrating equation. For Ghana at none and at most 1 in Table 4, there is no cointegrating equation; this means that there is no relationship between the variables in the specified model, with the same results for Kenya. For Nigeria there exists one cointegrating equation; this is indicated by the $p$-value of less than 0.05 at

TABLE 3e: Johansen Fisher panel cointegration tests.

\begin{tabular}{lccc}
\hline Hypothesised no. of CE(s) & $\begin{array}{c}\text { Fisher stat. } \\
\text { (from trace test) }\end{array}$ & Probability & $\begin{array}{c}\text { Fisher stat. } \\
\text { (from max-eigen test) }\end{array}$ \\
\hline None & 37.79 & 0.0000 & 27.30 \\
At most 1 & 18.05 & 0.0542 & 15.53 \\
At most 2 & 10.12 & 0.4303 & 8.274 \\
At most 3 & 10.18 & 0.3725 & 0.1139 \\
\hline
\end{tabular}

Probabilities are computed using asymptotic Chi-square distribution; CE (s), cointegrating equation(s); Lags interval (in first differences): 11.

TABLE 4: Individual cross section results, 1980-2014.

\begin{tabular}{|c|c|c|c|c|}
\hline Cross section & Trace test statistics & Probability** & Maximum eigen test statistics & Probability** \\
\hline \multicolumn{5}{|c|}{ Hypothesis of no cointegration } \\
\hline Botswana & 46.9689 & 0.0604 & 27.9295 & 0.0452 \\
\hline Ghana & 38.1925 & 0.2937 & 22.5343 & 0.1942 \\
\hline Kenya & 42.9380 & 0.1341 & 19.0267 & 0.4125 \\
\hline Nigeria & 54.8672 & 0.0095 & 25.3259 & 0.0947 \\
\hline South Africa & 67.4850 & 0.0003 & 35.8778 & 0.0034 \\
\hline \multicolumn{5}{|c|}{ Hypothesis of at most 1 cointegration relationship } \\
\hline Botswana & 19.0395 & 0.4901 & 14.5152 & 0.3243 \\
\hline Ghana & 15.6581 & 0.7361 & 9.9845 & 0.7461 \\
\hline Kenya & 23.9113 & 0.2042 & 14.7047 & 0.3101 \\
\hline Nigeria & 29.5413 & 0.0535 & 14.1105 & 0.3560 \\
\hline South Africa & 31.6072 & 0.0306 & 24.5454 & 0.0159 \\
\hline
\end{tabular}

**, Indicates significance at $5 \%$ level. 
TABLE 5: Autoregressive distributive lag test results, 1980-2014.

\begin{tabular}{lcc}
\hline Variables & Coefficient & Probability \\
\hline BCG & 0.454029 & 0.0000 \\
LLG & 0.036156 & 0.3744 \\
BDG & -0.368470 & 0.0000 \\
Speed of adjustment & -0.872186 & - \\
DBCG & -0.436079 & 0.0307 \\
DLLG & -0.363395 & 0.0130 \\
DBDG & 0.335016 & 0.0039 \\
\hline
\end{tabular}

$B C G$, bank credit to the private sector as proportion of GDP; LLG, ratio of liquid liabilities to GDP; BDG, ratio bank deposits as a percentage of GDP; DBCG, differenced bank credit to the private sector as proportion of GDP; DLLG, differenced ratio of liquid liabilities to GDP; DBDG, differenced ratio bank deposits as a percentage of GDP.

none under the trace statistic. For South Africa, the $p$-values from both at none and at most 1 are below 0.05 . This implies that for South Africa there exist two cointegrating equations; the trace and maximum eigenvalue tests at none indicate one cointegrating equation and at most 1 indicate another cointegrating equation.

The autoregressive distributed lag (ARDL) test results provide estimates of the long- and short-run relationships (Table 5). The long-run equation results indicate the influence that each indicator of financial sector development (BCG, LLG and BDG) has on economic growth. Table 5 further indicates the short-run estimates obtained from differenced variables (DBCG, DLLG and DBDG) and the speed of adjustment for the model to come back to equilibrium.

Table 5 indicates that bank credit to the private sector and liquid liabilities have a long-run positive influence on economic growth, with gross domestic savings exhibiting a negative influence. This implies that a $1 \%$ change in bank credit to the private sector would result in a $45.4 \%$ increase in economic growth in sub-Saharan African countries. With liquid liabilities, a $1 \%$ increase would lead to a $3.6 \%$ increase in economic growth. This conforms to the supply-following hypothesis, where financial development promotes economic growth. The results are consistent with some financial development-growth nexus researchers who found that financial systems have the ability to influence investment decisions, technological innovation and economic growth (Levine 2005). Furthermore, findings by Adu et al. (2013), Calderon and Lin (2002), Ahmed and Malik (2009) and Levine (1997) indicated a positive influence of bank credit to the private sector and liquid liabilities on economic growth.

For gross domestic savings, there exists a negative influence towards economic growth. If domestic savings were to increase by $1.0 \%$, economic growth would decline by $36.8 \%$. This implies a demand-following hypothesis where the demand for savings depends upon the growth of output. This negative influence means that economic growth would increase if domestic savings decrease, which in essence contradicts the theory. The negative influence of domestic savings corresponds to the results obtained by Obradovic and Grbic (2015), indicating that too much finance can exert a negative influence on economic growth; a higher savings rate indicates the presence of too much finance in the sub-Saharan African economies.

The speed of adjustment represents by how much percentage equilibrium will be restored in the next period. About $87.22 \%$ of the disequilibrium in the economy will be restored in the next coming year if changes are made to indicators of financial sector development in accordance with their respective influences. This means that if there are financial development imbalances in the economy in 1 year, $87.22 \%$ of those imbalances will be corrected in the next year.

In the short run, there is a significant negative influence of bank credit to the private sector and liquid liabilities on economic growth at $5 \%$ (Table 5). However, for gross domestic savings, there is a significant short-run positive relationship at $1 \%$. According to Rioja and Valev (2004), some indexes of financial development have a negative effect on economic growth. It turns out that for the selected sub-Saharan African countries, bank credit to the private sector and liquid liabilities positively influence economic growth in the long run. Moreover, gross domestic savings positively influence economic growth in the short run.

\section{Impulse response function results}

The impulse response test results are presented in Figure 1. The results looked at the response of economic growth to innovations in each variable for 10 periods.

Figure 1a depicts the response of economic growth to itself; from first to the tenth period, the response is positive. This means that any innovations in economic growth will result in a positive response towards economic growth. Figure $1 \mathrm{~b}$ shows that the response of economic growth to bank credit to the private sector is negative. This means that any innovations in bank credit to the private sector will adversely impact economic growth. In Figure 1c, the response of economic growth to liquid liabilities is negative from the first to the tenth period. The same negative response is indicated in Figure 1d, where the response of economic growth to gross domestic savings is negative. The results indicate that economic growth responds positively to its own shocks, and negatively to the shocks of indicators of financial sector development.

\section{Variance decomposition}

Variance decomposition results are presented in Table 6. The results are in percentages and indicate by how much a shock in each variable influences the dependent variable economic growth.

Table 6 indicates that economic growth is mainly shocked by its own innovations, which correlate with the impulse response function in Figure 1a. This is indicated by significant values of the shocks from the first to the tenth period. The shock by bank credit to the private sector is insignificant as the values are very low. This means that bank credit to the 

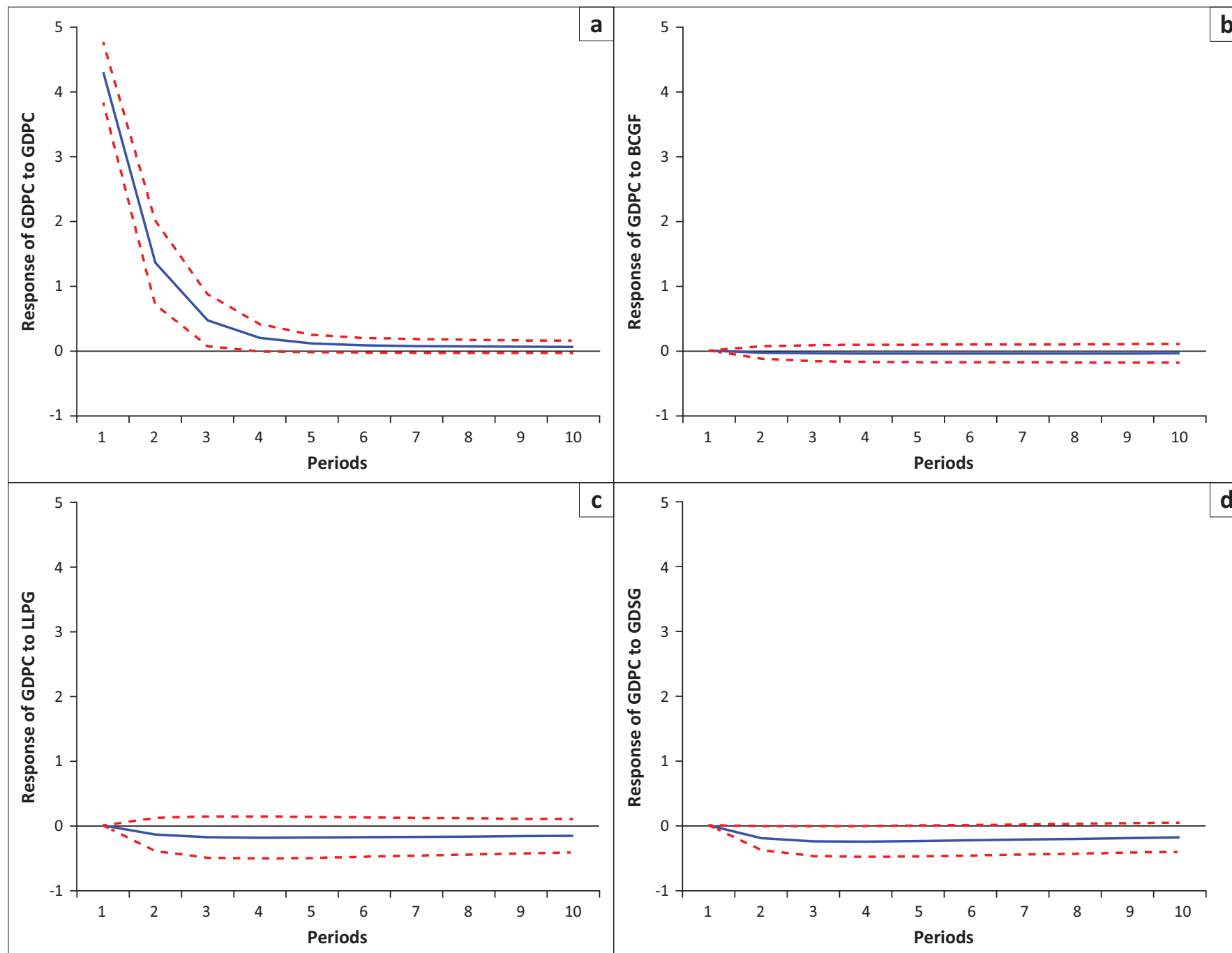

SD, standard deviation; SE, standard error; GDPC, gross domestic product; BCGF, bank credit to private sector; LLPG, liquid liabilities; GDSG, bank deposits.

FIGURE 1: Impulse response function results, 1980-2014. Response to Cholesky, one SD innovations \pm 2 SE. (a) response of GDPC to GDPC, (b) response of GDPC to BCGF, (c) response of GDPC to LLPG, response of GDPC to GDSG.

TABLE 6: Variance decomposition results of GDPC, 1980-2014.

\begin{tabular}{lcccc}
\hline Period & SE & GDP & BCG & LLG \\
\hline 1 & 4.311330 & 100.0000 & 0.000000 & 0.000000 \\
2 & 4.528573 & 99.71179 & 0.004511 & 0.095530 \\
3 & 4.563197 & 99.26635 & 0.011968 & 0.000000 \\
4 & 4.578283 & 98.79827 & 0.020410 & 0.188172 \\
5 & 4.589960 & 98.35512 & 0.029049 & 0.410908 \\
6 & 4.600236 & 97.94853 & 0.037621 & 0.570700 \\
7 & 4.609502 & 97.57913 & 0.046035 & 0.721701 \\
8 & 4.617902 & 97.24456 & 0.054256 & 0.862898 \\
9 & 4.625523 & 96.94190 & 0.062266 & 0.994382 \\
10 & 4.632436 & 96.66823 & 0.070056 & 1.045133 \\
\hline
\end{tabular}

SE, standard errors; GDP, annual growth rate of gross domestic product; BCG, bank credit to the private sector as proportion of GDP; LLG, ratio of liquid liabilities to GDP; BDG, ratio bank deposits as a percentage of GDP.

private sector innovations will provide little shock to economic growth in all the periods. For liquid liabilities, the shock from the innovation is significant in the ninth and tenth periods, meaning that in those two periods any innovations in liquid liabilities will result in a response from economic growth. For gross domestic savings, the shock is felt from the fifth to the tenth period. Any innovation in gross domestic savings will result in a positive response from economic growth in the periods specified.
After running the ADRL model, some diagnostic tests were conducted to find out if the estimated model is best fit. The series is normally distributed as indicated by the kurtosis value of 12.6, which is way above 3 (Asteriou \& Hall 2011). The null hypothesis of Lagrange Multiplier serial correlation test results indicates that there is no serial correlation because the probability values of all lags are greater than the $p$-value of 0.05 . 


\section{Conclusion and recommendations}

The aim of this article was to determine the influence of financial sector development on economic growth in five selected sub-Saharan African countries. Economic growth was regressed against bank credit to the private sector, liquid liabilities and gross domestic savings. Panel cointegration, panel ARDL, variance decomposition and impulse response were employed in the analysis.

The stationarity test results were obtained at different orders of integration, giving a go-ahead in the application of ARDL. From the different cointegration tests performed, it is found that there is a presence of a long-run relationship between the variables, except the Kao test which failed to find the relationship. The ARDL test results indicated that in the long run, bank credit to the private sector and liquid liabilities influence economic growth positively, which exhibits the supply-following hypothesis, which states that financial sector development causes economic growth. This implies that bank credit to the private sector and liquid liabilities will contribute positively to the growth of the economy. For domestic savings, the results indicated a negative influence of domestic savings to economic growth in the long run. However, opposite results were obtained in the short run, where gross domestic savings had a positive influence on economic growth.

The speed of adjustment was significant in all the countries combined and showed that the series would come to equilibrium at a speed of about $87 \%$. Both the impulse response function and the variance decomposition results indicated that economic growth is mainly shocked by itself and by its own innovations. However, for the variance decomposition, the shocks are not felt immediately for all the variables' shocking economic growth. For instance, for gross domestic savings, the shocks become significant from the fifth period. The entire results outline the influence that financial sector development has towards economic growth.

In conclusion, there exist short- and long-run relationships between financial sector development and economic growth. Two indicators of financial sector development (bank credit to private sector and liquid liabilities) influenced economic growth positively, while one (savings) indicator influenced economic growth negatively in the long run. For forecasting, the results show that as time progresses, innovations in economic growth will mainly influence itself. For variance decomposition, as indicated by the significant values, economic growth is affected by its own shocks, and the shocks of indicators are significant in different periods.

This article therefore makes recommendations that as financial stability, globally and within countries, generates jobs and improves productivity, more effort should be made to ensure an effective and developed financial sector system. The positive relationship between credit instruments and economic growth needs to be improved, especially in the African context. This is so because limited and inadequate access to credit contributes significantly to low productivity in agriculture in rural areas, limits the contributions of small and mediumsized enterprises to private sector development and can slow the deepening of the banking sector in oil-exporting countries as declining export revenues affect their foreign assets.

\section{Acknowledgements}

The authors thank the Economic Research of Southern Africa (ERSA) for financially assisting the project, which resulted in the writing of this article.

\section{Competing interests}

The authors declare that there are no competing interests.

\section{Authors' contributions}

K.M. and T.N. contributed equally to the writing of this article.

\section{References}

Acaravci, S.K., Ozturk, I. \& Acaravci, A., 2009, 'Financial development and economic growth: Literature survey and empirical evidence from Sub-Saharan African countries', South African Journal of Economics and Management Sciences 12(1), 11-27. https://doi.org/10.4102/sajems.v12i1.258

Ackah, C. \& Asiamah, J.P., 2014, Financial regulation in Ghana: Balancing inclusive growth with financial stability, Bank of Ghana working paper no. 410, Overseas Development Institute, London.

Adu, G., Marbuah, G. \& Mensah, J.T., 2013, 'Financial development and economic growth in Ghana: Does the measure of financial development matter?', Review of Development Finance 3(1), 193-203. https://doi.org/10.1016/j.rdf.2013.11.001

Ahmed, E. \& Malik, A., 2009, 'Financial sector development and economic growth: An empirical analysis of developing countries', Journal of Economic Cooperation and Development 1(1), 17-40.

Ajide, K.B., 2014, 'Determinants of economic growth in Nigeria', CBN Journal of Applied Statistics 5(2), 147-170.

Akinboade, O.A., 1998, 'Financial development and economic growth in Botswana: A test for causality', Savings and Development 22(3), 331-348.

Akinboade, O.A. \& Makina, D., 2006, 'Financial sector development in South Africa: 1970-2002', Journal of Study in Economics and Econometrics 30(1), 101-127.

Akinlo, A.-E. \& Egbetunde, T., 2010, 'Financial sector development and economic growth: The experience of 10 Sub-Saharan African countries revisited', The Review of Finance and Banking 2(1), 17-28.

Al-Zubi, K., Al-Rjoub, S. \& Abu-Mhareb, E., 2006, 'Financial development and economic growth: A new empirical evidence from the Mena countries, 1989-2001', Applied Econometrics and International Development 6(3), 137-150.

Amusa, K. \& Busani, M., 2013, 'Savings and economic growth in Botswana: An analysis using bounds testing approach to cointegration', Journal of Economics and Behavioural Studies 5(4), 200-209.

Antwi-Asare, T.O. \& Addison, E.K., 2000, Financial sector reforms and bank performance in Ghana, Overseas Development Institute, University of Ghana.

Arcand, J.E.B. \& Panizza, U., 2012, Too much finance? International Monetary Fund Research Department, Washington, DC

Asteriou, D. \& Hall, S.G., 2011, Applied econometrics, 2nd edn., Palgrave Macmillan, New York.

Balago, G.S., 2014, 'Financial sector development and economic growth in Nigeria: An empirical investigation', International Journal of Finance and Accounting 3(4), 253-265.

Bank of Botswana, 2009, Banking supervision annual report, Bank Library, Gaborone. Bank of Botswana, 2015, Banking supervision annual report, Bank Library, Gaborone. Bara, A., Mugano, G. \& Le Roux, P., 2016, 'Financial innovation and economic growth in SADC', Economic Research Southern Africa working paper 627, 1-22.

Bara, A., Mugano, G. \& Le Roux, P., 2016, 'Financial development and economic growth in the SADC. African journal of Science, Technology, Innovation and Development 8(5), 483-495.

Beck, T., Demirgüç-Kunt, A., Levine, R. \& Maksimovic, 2001, Financial structure and economic development: Firm, industry and country evidence in financial structure
and economic growth a cross country comparison of banks, markets and and economic growth a cross country comparison
development, pp. 189-242, MIT press, Cambridge, MA. 
Beck, T. \& Fuchs, M., 2004, Structural issues in the Kenyan financial system: Improving competition and access, World Bank Policy Research Working paper no. 3363, World Bank, Washington, DC. https://openknowledge.worldbank.org/handle/10986/14185 Bank, Washington, DC.
License: CC BY 3.0 IGO.

Bidirici, M. \& Bohur, E., 2015, 'Design and economic growth: Panel cointegration and causality analysis', Social and Behavioral Sciences 210, 1-94. https://doi. org/10.1016/j.sbspro.2015.11.359

Bildirici, M., 2004, 'Real cost of employment and Turkish labour market: A panel cointegration test approach', International Journal of Applied Econometrics and Quantitative Studies 1(2), 1-29.

Boulika \& Trabelisi, 2002, Financial development and long-run growth: Grange causality in bivariate VAR structure, evidence from Tunisia: 1962-1997, viewed 25 July 2017, from www.erf.org.eg/CMS/getfile.php?id=700

Calderon, C. \& Lin, L., 2002, The direction of causality between financial development and economic growth, Central Bank of Chile working paper 184, Central Bank of Chile, Santiago.

Cecchetti, G. \& Kharroubi, E., 2012, Reassessing the impact of finance on growth, BIS working paper no. 38, Bank for International Settlements, Switzerland.

Chete, L.N., Adeoti, J.O., Adeyink, F.M. \& Ogundele, O., 2014, Industrial development and growth in Nigeria: Lessons and challenges, Nigerian Institute of Social and Economic Research, Learning to complete working paper no. 8, Brookings Institution, Ibadan.

Deloitte, 2016, Kenya economic outlook 2016 report: The story behind the numbers, Global Economic Outlook, Nairobi.

Den Haan Wouter, J., 2011, Impulse response functions, University of Amsterdam, Amsterdam.

Egbetunde, T. \& Fasanya, I.O., 2013, 'Public expenditure and economic growth in Nigeria: Evidence from auto-regressive distributed lag specification', Zagreb International Review of Economics 16(1), 70-92.

Ekmekcioglu, E., 2012, The relationship between financial development and economic growth in emerging markets, Turan University, Almaty-Kazakistan.

Estrada, G., Park, D. \& Ramayadi, A., 2010, Financial development and economic growth in developing Asia, ADB Economics working paper series no 233, Asian Development Bank Institute, Mandaluyong City. http://hdl.handle.net/11540/5104

European Investment Bank (EIB), 2016, Financial Report, viewed 25 June 2017, from www.eib.org

Goldsmith, R.W., 1989, Financial policies, growth and efficiency, World bank working paper 202, World Bank, Washington, DC. http://documents.worldbank.org/ curated/en/878761468740137322/Financial-policies-growth-and-efficiency

Gulde, A.-M., Pattillo, C., Christensen, J., Carey, K. \& Wagn, S., 2006, Sub- Saharan Africa: Financial sector challenges, International Monetary Fund, Washington, DC.

Harjes, T. \& Ricci, L.A., 2008, A Bayesian estimated model of inflation targeting in South Africa, IMF working paper 8 no. 48, International monetary fund, Washington, DC

Hassan, K., Sanchez, B. \& Yu, J.-S., 2009, 'Financial development and economic growth in the organization of Islamic conference countries', Journal of King Abdul Aziz University-Islamic Economics 1-38.

Hassan, K.M., Sanchez, B. \& Yu, J.-S., 2011, 'Financial development and economic growth: New evidence from panel data', The Quarterly Review of Economics and Finance 51(1), 88-104.

Hoang, T.N., 2007, Essays on panel unit roots and panel cointegration tests, University of Colorado, Colorado, pp. 1-94.

IPS: Im, K.S., Pesaran, M.H. \& Shin, Y., 2003, 'Testing for unit roots in heterogeneous panels', Journal of Econometrics 115 (revised version of 1997's work), 53-74.

Kao, C., 1999, 'Spurious regression and Residual-based Tests for cointegration in Panel Data', Journal of Econometrics 90, 1-44. https://doi.org/10.1016/S0304-4076(98)00023-2

Karikari, N., Mensah, S. \& Harvey, S., 2016, 'Do remittances promote financial development in Africa?', Springer Plus 5(1011), 1-21. https://doi.org/10.1186/ s40064-016-2658-7

Khan, M.A. \& Abbas, F., 2016, 'The dynamics of electricity demand in Pakistan: A panel cointegration analysis', Journal of Renewable and Sustainable Energy 65, 11591178. https://doi.org/10.1016/j.rser.2016.06.054

Khan, R., 2017, Africa: Economic growth-vital trends to watch in Africa, All Africa, Uganda.

King, R.G. \& Levine, R., 1993, 'Finance and growth: Schumpeter might be right', The Quarterly Journal of Economics 108(3), 717-737. https://doi.org/10.2307/2118406

Krentz, A., 2012, A panel cointegration analysis of industrial and services sectors agglomeration in the European Union, Centre for European, Governance and Economic Development Research, Discussion paper 146, University of Goettingen, Department of Economics.

Law, S.H., Azman-Saini, W. \& Ibrahim, M.H., 2013, 'Institutional quality threshold and the finance-growth nexus', Journal of Banking and Finance 37(12), 5373-5381. https://doi.org/10.1016/j.jbankfin.2013.03.011

Law, S.H. \& Singh, N., 2014, 'Does too much finance harm economic growth?', Journal of Banking and Finance 41(2014), 36-44. https://doi.org/10.1016/j.jbankfin.2013.12.020

Lehlola, P., 2017, Recession: South African economy shrinks by $0.7 \%$, viewed 12 October 2017, from Business report live: http://www.iol.co.za/business report/ recession-south-african-economy-shrinks-by-07-9585516

Levine, R., 1997, 'Financial development and economic growth: Views and agendas', Journal of Economic Literature 35(1), 688-728.
Levine, R., 2005, 'Finance and growth: Theory and evidence', Handbook of Economic Growth 1(A), 865-876.

Loayza, N.V. \& Ranciere, R., 2006, 'Financial development, financial fragility and growth', Journal of Money, Credit and Banking 38(4), 1051-1076. https://doi. org/10.1353/mcb.2006.0060

Macias, J.B. \& Massa, I., 2009, The global financial crisis and Sub-Saharan Africa: The effects of slowing private capital inflows on growth, Overseas Development Institute working paper no. 304, Overseas Development Institute, London.

Maddala, G.S. \& Wu, S., 1999, 'A comparative study of unit root tests with panel data and new simple test', Oxford Bulletin of Economics and Statistics, Special Issue 61(S1), 631-652.

Madigele, P.K. \& Mogomotsi, G.E., 2016, 'Improving financial inclusion of the socially and economically disadvantaged in Botswana through the Grameen bank microcredit model', Botswana Journal of Business 9(1), 55-65.

Maipose, G.S., 2008, Institutional dynamics of sustained rapid economic growth with limited impact on poverty alleviation, United Nations Publication, New York.

Moffat, B., 2009, 'The baking environment in Botswana: An overview', Botswana Notes \& Records 41, 95-103.

Mogale, P., 2014, Financial sector development and economic growth in SADC, South African Reserve Bank Publication, Pretoria.

National Treasury RSA, 2011, A safer financial sector to serve South Africa better, National Treasury Policy Document, Pretoria.

Ndlovu, G., 2013, 'Financial sector development and economic growth: Evidence from Zimbabwe', International Journal of Economics and Financial Issues 3(2), 435-446.

Ngongang, E., 2015, 'Financial development and economic growth in Sub-Saharan Africa: A dynamic panel data analysis', European Journal of Sustainable
Development 4(2), 369-378. https://doi.org/10.14207/ejsd.2015.v4n2p369

Nzotta, S. \& Okereke, E., 2009, 'Financial deepening and economic development of Nigeria: An empirical investigation', African Journal of Accounting, Economics, Finance and Banking Research 5(5), 25-31.

Obradovic, S. \& Grbic, M., 2015, 'Causality relationship between financial intermediation by banks and economic growth: Evidence from Serbia', Ministry of Science and Technological Development of the Republic of Serbia, Serbia: Prague Economic Papers, 24(1), 60-72. https://doi.org/10.18267/j.pep.500

Odhiambo, N.M., 2009, 'Interest rate liberalization, financial deepening and economic growth in South Africa: An empirical investigation', in IBER and TLC conference proceedings, Las Vegas, NV, May 05, 2017, pp. 541-557.

Odhiambo, N.M., 2010, 'Finance-investment-growth nexus in South Africa: An ARDLbounds testing procedure', Economic Change and Restructuring 43, 205-219. https://doi.org/10.1007/s10644-010-9085-5

Olofin, S. \& Afangideh, U.J., 2008, 'Financial structure and economic growth in Nigeria', Nigeria Journal of Securities and Finance 1(1), 47-68.

Oluitan, R.O., 2012, 'Bank credit and economic growth: Evidence from Nigeria', International Business and Management 5(2), 102-110.

Pedroni, P., 1997, Panel cointegration; Asymptotic and finite sample properties of pooled time series tests, with an application to the PPP Hypothesis: New results, Working paper, Indiana University. Bloomington, IN.

Pesaran, H.M. 2012, 'On the interpretation of panel unit root tests', Economics Letters 116, 545-546. https://doi.org/10.1016/j.econlet.2012.04.049.

Quartey, P., 2005, Financial sector development, savings mobilization and poverty reduction in Ghana, Research Paper no. 2005/71, United Nations University, New York.

Quartey, P. \& Prah, F., 2008, 'Financial development and economic growth in Ghana: Is there a causal link?', The African Finance Journal 10(1), 28-54.

Ramirez, M.D., 2006, 'A panel unit root and panel cointegration test of the complementarity hypothesis in the Mexican case, 1960-2001', Economic Growth Centre: Discussion paper 942, 1-29.

Rashti, N.A., Araghi, E.S. \& Shayeste, M., 2014, 'Relationship between financial development and economic growth, evidence from financial crisis', Asian Economic and Financial Review 4(1), 930-940.

Rioja, F. \& Valev, N., 2004, 'Finance and the sources of growth at various stages of economic development', Economic Inquiry 42, 127-140. https://doi.org/10.1093/ei/cbh049

Romer, P., 1986, 'Increasing returns and long run growth', Journal of Political Economy 94(1), 1002-1037. https://doi.org/10.1086/261420

Samargandi, N., Fidrmuc, J. \& Ghosh, S., 2014, 'Is the relationship between financial development and economic growth monotonic? Evidence from a sample of middle-income countries', Journal of World Development 68(1), 66-81.

Siane, L., 2005, 'The role of financial sector development in economic growth: Case study of Botswana', Masters dissertation from University of Cape Town.

United Nations, 1997, Kenya's financial sector: Institutional structure evolution and resource, evolution and resource mobilization for development, Economic and Social Council, New York.

Verbeek, M., 2004, A guide to Modern Econometrics, 2nd edn., Erasmus University Rotterdam, John Wiley and Sons, Ltd. England.

World Bank, 2016, World Development Indicators, viewed 06 March 2017, from www. worldbank.org

Xu, Z., 2000, 'Financial development, investment and economic growth', Economic Enquiry 38(2), 331-344. https://doi.org/10.1111/j.1465-7295.2000. tb00021.x 